\title{
Cover crops as green mulching for weed management in rice
}

\author{
Silvia Fogliatto, Lorenzo Patrucco, Fernando De Palo, Barbara Moretti, Marco Milan, \\ Francesco Vidotto \\ Dipartimento di Scienze Agrarie, Forestali e Alimentari, Università degli Studi di Torino, Grugliasco (TO), \\ Italy
}

\section{Highlights}

- Green mulching reduces weed pressure, but it should be integrated with other weed control techniques.

- Hairy vetch showed poor establishment because of the combination of scarce emergence due to sod-seeding and low temperatures.

- Italian ryegrass was more tolerant to low temperatures and showed a good cover that contained weed growth.

- Cover crop mixture showed variable results with higher suppression probably related to the number of cover crop species present in the mixture.

- $\quad$ The termination methods (crimping and shredding) did not affect weed density and rice yield.

\begin{abstract}
A field study was carried out in 2017 and 2018 in two Italian rice farms (at Livorno Ferraris and Rovasenda) to assess the effect of using cover crops as green mulching on weed control and rice yield. Three different rice fields were sown in each site after rice harvest with either Vicia villosa, Lolium multiflorum, or a mixture of both ( $V$. villosa $40 \%+L$. multiflorum $60 \%$ ); at Rovasenda, a small percentage of Brassica napus and Triticale was also present in the mixture. An additional field at both sites without cover crop was considered as a control reference. Rice was broadcasted sown within the cover crop in May. After few days, the cover crop was terminated in half of each field using a roller-crimper, while in the
\end{abstract}

Correspondence: Silvia Fogliatto, Dipartimento di Scienze Agrarie, Forestali e Alimentari, Università degli Studi di Torino, Grugliasco (TO), Italy.

E-mail: silvia.fogliatto@unito.it

Key words: Italian ryegrass; hairy vetch; mixture; termination; rollercrimper; shredding; weed suppression.

Funding: the study was funded by the project 'Risobiosystems' (Progetto di ricerca, sviluppo e sostegno della risicoltura biologica) promoted by MIPAAF (CUP code: C65I16000190001).

Received for publication: 24 February 2021.

Revision received: 21 July 2021.

Accepted for publication: 26 July 2021.

(C) Copyright: the Author(s), 2021

Licensee PAGEPress, Italy

Italian Journal of Agronomy 2021; 16:1850

doi:10.4081/ija.2021.1850

This article is distributed under the terms of the Creative Commons Attribution Noncommercial License (by-nc 4.0) which permits any noncommercial use, distribution, and reproduction in any medium, provided the original author(s) and source are credited. other half, it was terminated by shredding. Within 10 days, the fields were flooded for about a week to promote the degradation of the cover crop biomass. Then, the fields were cultivated in flooding conditions without further weed control. Weed density and weed cover were evaluated three times during the growing season. At harvest, rice yield and harvest index were determined. Mixed nested Mixed nested ANOVAs were performed for each site to assess the effect of cover crop species, termination technique, and the interaction between cover crop and year. L. multiflorum showed high biomass before termination, while $V$. villosa had a more variable development. At Rovasenda, $V$. villos a growth was limited because of the combination of scarce emergence due to sod-seeding and frost damage. In general, green mulching significantly affected weed density. The best weed suppression was observed with $L$. multiflorum and mix at Rovasenda, with values of weed density $<40$ plants $\mathrm{m}^{-2}$ recorded in 2018 . At both sites, rice yield was variable in the two years. The highest rice yield $(>5$ $\mathrm{t} \mathrm{ha}^{-1}$ ) was observed in 2018 in the shredded mixture at Rovasenda and in $V$. villosa at Livorno Ferraris in 2017. Generally, control fields showed lower yields (1-3 tha $\left.{ }^{-1}\right)$ at both sites. The termination methods did not significantly affect both weed density and rice yield. The results highlighted that green mulching could reduce weed infestations, even though alone is not able to avoid weed development completely. Some critical issues of the technique were observed, such as the need for a good cover crop establishment which eventually results in abundant biomass production and significant weed suppression.

\section{Introduction}

Among the European countries, Italy is the most relevant rice (Oryza sativa L.) producer. Italian rice cultivation is mainly concentrated in two northern regions: Piedmont and Lombardy, with about 230,000 ha, which accounted for about $93 \%$ of the total Italian rice area (Ranghetti et al., 2018; Ente Nazionale Risi, 2021).

The highly concentrated area of rice production in a relatively small territory, the common practice of rice monocropping, and the control of weeds mainly based on the use of herbicides have 
made weed management more and more challenging, with the development of highly specialized weed flora and the spread of herbicide-resistant weeds (Andres et al., 2014; Serra et al., 2018; Ferrero et al., 2020). Together with the reduction of the number of available herbicides, due to strict European regulations that have brought out of the market many active substances, these problems call for finding more sustainable integrated weed management strategies (Lamichhane et al., 2016; Vidotto et al., 2020).

The most well-known and diffused techniques to limit weed infestations other than herbicide use are mainly based on enhancing plant ability to compete with weeds, such as increased sowing rate (Chauhan et al., 2011), use more competitive varieties, and adopting crop rotation (Pardo et al., 2021), or controlling weeds with thermal or mechanical methods (Stepanovic et al., 2016). In rice, due to its peculiarity, some of the methods used in other crops are more difficult to apply, such as some mechanical techniques (i.e., weed hoeing) that can be problematic for the presence of water in the field (Chauhan, 2012). However, other techniques are already integrated into chemical weed control in conventional rice production or as the only available tools in organic farming (Fogliatto et al., 2020b). Among these, the use of false seedbed technique, a good soil levelling to obtain a uniform water depth, and rice transplanting, to favour earlier and faster rice growth compared to weeds, are the most widespread (Dass et al., 2017; Shekhawat et al., 2020).

In this context, cover crops can play a key role as they can cover the ground with a considerable amount of biomass, suppressing weeds thanks to competition and, after termination, contributing to release nutrients to the crop (Didon et al., 2014; Osipitan et al., 2018). Moreover, cover crops can reduce weed density in the early growth stages without altering crop yield and reduce weed seed production in autumn through growth competition (Osipitan et al., 2018; Youngerman et al., 2018).

Cover crops can suppress weeds not only by exerting competition but also by releasing allelopathic compounds while they are growing or during the degradation of their residues (Kruidhof et al., 2014; Gerhards and Schappert, 2020).

The most widespread practices of cover crop termination are soil incorporation which leaves the soil bare just before sowing, or by using total herbicides, i.e., glyphosate, to completely devitalize the plants and obtain a dead mulch left on the soil (Kruidhof et al., 2014; Cornelius and Bradley, 2017a; Fogliatto et al., 2020a). Tillage and mowing are also other techniques used to terminate, in particular, winter-hardy cover crop species (Lounsbury and Weil, 2015).

Recently, the use of roller-crimper to terminate cover crops has increased as it permits reduction of fuel and time compared to shredding and because it creates a uniform layer of cover crop residues on the soil surface which physically obstructs weed emergence (Bavougian et al., 2018). This residue layer also limits the amount of light and heat that can reach the soil and thus interferes with seed germination (Bavougian et al., 2018). In addition, shredding of cover crops produces small size residues that are more easily degradable, giving an uneven cover with a shorter duration of the physical weed suppression effect than in the case of roller crimping, in which plant residues are deposited more uniformly in travel direction (Dorn et al., 2013; Ackroyd et al., 2019).

Green mulching is a technique that has recently been applied in Italian rice production, especially in organic systems, which consists of growing cover crop species during autumn and winter and flooding the field after their termination (by shredding or roller-crimping) to start the degradation of the biomass and the potential production of phytotoxic compounds, such as organic acid (acetic, butyric, and propionic acids) (Camargo et al., 2001; Fogliatto et al., 2019; Orlando et al., 2020). In this case, rice is often sown before cover crop termination. Thus, green mulching could be effective in reducing weed density both because of a physical effect exerted by cover crop residues, which can reduce seed germination and hamper weed emergence, and because of the production of phytotoxic compounds due to biomass fermentation in anaerobic conditions as a consequence of field flooding (Fogliatto et al., 2019; Orlando et al., 2020). Even though the suppressive effect of cover crops on weeds is known and has been largely studied, the effect of green mulching on flooded rice fields has been tested only by farmers but never investigated in detail.

The objective of the study, conducted in two rice farms in North-west Italy in 2017 and 2018, was to evaluate the effectiveness of green mulching with three different cover crops, Italian ryegrass (Lolium multiflorum Lam.), hairy vetch (Vicia villosa Roth), and a mixture of the two, on weed development and rice yield.

The study also aimed at defining which cover crop termination technique (shredding or roller crimping) resulted in more effective weed control.

\section{Materials and methods}

\section{Site description}

The experiments were conducted in two different sites about $40 \mathrm{~km}$ apart, Rovasenda and Livorno Ferraris, both located in Vercelli province, Piedmont (North-West Italy). The trials were repeated in both farms in 2017 and 2018.

In the Italian rice area, the climate is temperate with moderately cold winters (average max and min in January are $+6^{\circ}$ and $-1{ }^{\circ} \mathrm{C}$, respectively), mild springs (average max and $\min$ in April $19^{\circ} / 9^{\circ} \mathrm{C}$ ) and hot summers $\left(31^{\circ} / 19^{\circ} \mathrm{C}\right.$ in July) (Arpa Piemonte, 2021). The average minimum and maximum temperatures and the total rainfall amount of each month during the study period (from $1^{\text {st }}$ October 2016 to $15^{\text {th }}$ September 2018) for each site are shown in Figure 1. Data were retrieved from the nearest available weather stations (few kilometres from the experimental sites, namely Crescentino station for Livorno Ferraris and Gattinara station for Rovasenda), managed by Regione Piemonte (Rete Agrometeorologica Regione Piemonte).

Rice in these areas is usually sown in flooded fields between mid-April and mid-May. According to the regional soil chart, soil textures of both farms can be classified as silty loam.

At Livorno Ferraris the same paddy fields $\left(45.2750^{\circ} \mathrm{N}\right.$, $8.1303^{\circ} \mathrm{E}$ ) were used in both years of the experiment and the preceding crop was rice; differently, in Rovasenda farm, due to crop rotation, the trial was not repeated in the same fields for both years but, in 2018, it was moved few meters away from the first site $\left(45.5386^{\circ} \mathrm{N}, 8.2968^{\circ} \mathrm{E}\right.$, and $45.5362^{\circ} \mathrm{N}, 8.2977^{\circ} \mathrm{E}$ in 2017 and 2018 , respectively). According to 2017 , the experimental field was cultivated with rice in the preceding year, while according to 2018 , the new fields were managed similarly to the older ones, but the preceding year they were cropped with soybean (Glycine max (L.) Merr.), followed by buckwheat (Fagopyrum esculentum Moench).

\section{Experimental design}

Three cover crops were seeded with centrifugal rice seeding spreader in early October, just after rice harvest, namely Italian ryegrass, hairy vetch, and a mix of these two (60\% Italian ryegrass, 
$40 \%$ hairy vetch) at Livorno Ferraris, while at Rovasenda the mix was also mainly constituted by Italian ryegrass and hairy vetch but a small percentage (about $5 \%$ of total weight) of canola (Brassica napus L.) and triticale ( $\times$ Triticosecale Wittmack) was added. The seed rates were $50 \mathrm{~kg} \mathrm{ha}^{-1}$ for Italian ryegrass and hairy vetch and $60 \mathrm{~kg} \mathrm{ha}^{-1}$ for the mix; these cover crop species were chosen among the most commonly used in Italy since they can grow fast even during wintertime, producing a good amount of biomass, and a sufficient soil coverage (Caporali et al., 2004; Fogliatto et al., 2019). At Livorno Ferraris, in both years, the experimental fields were mouldboard ploughed after rice harvest at $20 \mathrm{~cm}$ depth and harrowed twice (few days after ploughing) before cover crop seeding. At this site, cover crops were sown on $28^{\text {th }}$ September 2016, and $3^{\text {rd }}$ October 2017. At Rovasenda, in the first year of the experiment, the cover crops were sod-seeded on non-tilled fields (on $20^{\text {th }}$ October 2016), but their emergence was scarce, and the further growth was compromised. For this reason, in the second year also at Rovasenda, the experimental fields were mouldboard ploughed before cover crop seeding (end of September), and the cover crops were sowed earlier (on $9^{\text {th }}$ October 2017) to avoid having small plants at the first frost occurrence.

At both sites, the experimental design was arranged in four adjacent fields, with a size of about $5000 \mathrm{~m}^{-2}$ each, in which water was able to flow in and out independently. In three out of four fields, different cover crops were sown while the fourth was managed without sowing a cover crop (weedy fallow), to have a control treatment. Neither herbicides nor other weed control techniques were applied in the fields during the experiment. At both sites, rice was broadcasted sown at a density of $190 \mathrm{~kg}$ seeds ha ${ }^{-1}$ on $13^{\text {th }}$ May 2017, while in 2018 at Livorno Ferraris, rice was sown on $30^{\text {th }}$ April and at Rovasenda on $9^{\text {th }}$ May. At both sites, for both years, the chosen variety was Sant'Andrea. Right after rice sowing, each field was longitudinally divided into two halves in which the cover crops were mechanically terminated with one of the two tested techniques (shredding or using a roller-crimper), assigned randomly in each half, in order to evaluate if the termination technique could affect the weed development. The roller crimper had a diameter of $0.6 \mathrm{~m}$ and a width of about $3 \mathrm{~m}$ with blades arranged in an inverted ' $V$ ' pattern to avoid bouncing, while the shredder was $2 \mathrm{~m}$ wide with hard-surfaced blades. Each field was then ideally divided crosswise into three zones to obtain three pseudo-replicates in which assessments were carried out. Fields were flooded with a water layer of about $8-10 \mathrm{~cm}$ just after rice sowing (mid-May) to favour rice germination and cover crop biomass degradation. Fifteen days after rice sowing, all fields were drained for about 10 days. As soon as rice rooting occurred $(\mathrm{BBCH}$ growth stage: 10), fields were again flooded until rice harvesting.

\section{Cover crop and weed assessments}

Cover crop biomass was determined at both sites at the beginning of May each year, just before the termination of the cover crops, by randomly cutting the biomass in three areas of $0.5 \mathrm{~m}^{2}$ in each zone. Afterward, the biomass was oven-dried at $60^{\circ} \mathrm{C}$ for 72 $\mathrm{h}$ in a laboratory of the Department of Agricultural, Forest and Food Sciences of the University of Torino.

At both sites, weed density and weed cover over the soil surface were estimated one week before rice sowing and cover crop termination, and two times after sowing: once in June at the end of the drying period (12-14 BBCH growth stage of rice - leaf development) to check the effect of green mulching after the first flooding and once in July, during rice tillering (21-23 BBCH growth stage of rice) to assess the long-term effect of the technique. Weed density was assessed by counting the individuals of each weed species present within a square metal frame having a size of $50 \times 50$ $\mathrm{cm}$ randomly launched 18 times per field, 9 in the shredded portion and 9 in the roller crimped one. Weed cover was visually estimated by evaluating the soil portion covered by weeds in the same quadrat used for assessing weed density.

To assess the suppressive ability of the different cover crops adopted, for each combination of cover crop and termination technique, the relative neighbour effect index (RNE) was calculated by comparing the weed density present in each field with that present in the control (Smith et al., 2015; Alonso-Ayuso et al., 2018). The index was calculated for both years only on the weed assessment carried out in June, as in July, the weed vegetation was dominated by Heteranthera reniformis Ruiz \& Pav., which created an intricate vegetation mat that made it impossible to distinguish each plant. Therefore, the index was calculated as (Eq. 1):

$R N E=\frac{N_{\text {control }}-N_{c c}}{x}$

where $N_{\text {control }}$ is the weed density recorded in the control field, $N_{c c}$ the weed density recorded in each subplot having different cover crops and termination techniques, and $x$ the weed density of the greater terms (if $N_{\text {control }}>N_{c c}$ then $x=N_{\text {control }}$ and vice versa) (Smith et al., 2015; Alonso-Ayuso et al., 2018). Positive RNE values between 0 and 1 indicate a suppression weed ability of the cover crops, while an RNE of 0 corresponds to no-effect of the cover crops on weeds, and negative RNE values, between 0 and -1 , correspond to higher weed density in cover crop plots. Before calculating the index, the weeds were grouped in grass monocots, other monocots (species mainly belonging to the family Cyperaceae), and dicots, and the RNE index was calculated separately for each of these groups.
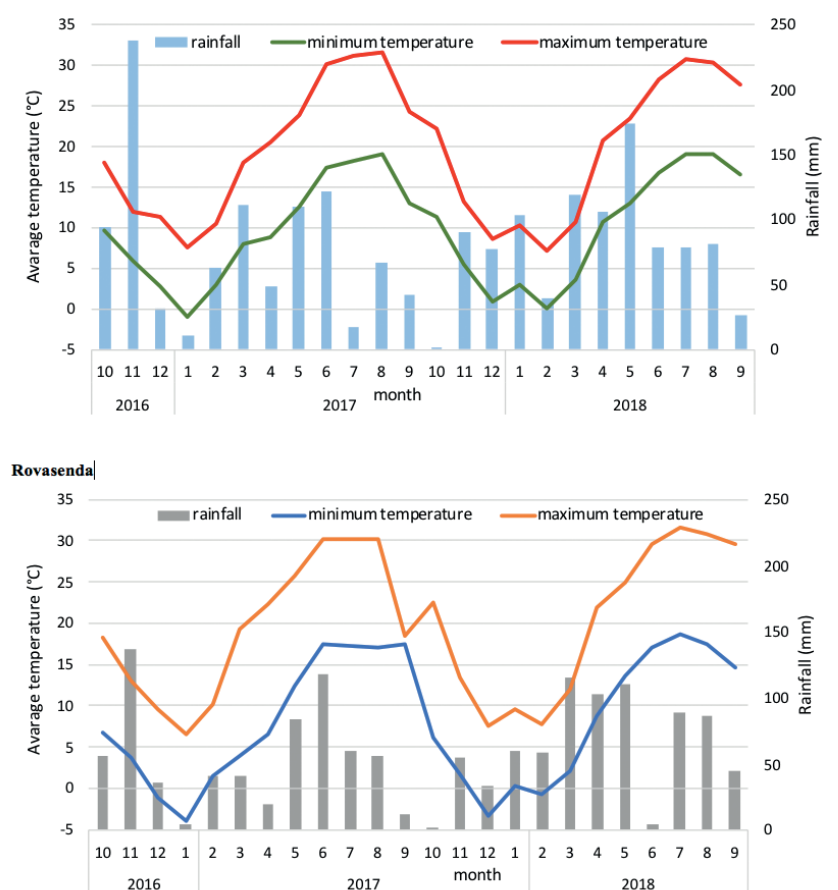

Livorno Ferraris

Figure 1. Average minimum and maximum temperatures and the total rainfall during the study period at Rovasenda (top) and Livorno Ferraris (bottom). 


\section{Rice yield}

At rice ripening (BBCH growth stage 89), which occurred in the last ten days of September, all rice plants present in four areas of a square meter size $(1 \times 1 \mathrm{~m})$ were randomly chosen in each zone for each combination of cover crop, and termination technique (if present) were manually cut at the base. Immediately after harvest, rice was weighed to determine the biomass and the harvest moisture. Rice grains were then separated from the culms and weighed separately to determine the average yield and the harvest index. Next, a sample of rice grain and culms per treatment were ovendried at $90^{\circ} \mathrm{C}$ to constant weight to determine moisture. Then, rice yield was expressed at $13 \%$ moisture content as a whole rice grain.

\section{Statistical analysis}

Plant biomass produced by the different cover crops before termination in each site was analysed using an analysis of variance (ANOVAs), considering the year as a random factor. For each site, different nested mixed ANOVAs were conducted to determine the effect of the year, the cover crop used, the termination techniques, and the interactions between year and cover crop on weed density, rice yield, and harvest index.

In particular, weed density differences between cover crops and the control were tested, separately for the three assessments, by means of ANOVA considering the following factors: zone (pseudo-replicate) nested in the cover crop, cover crop, year as a random factor, and the interaction between year and cover crop. The same analysis was also conducted on rice yield and harvest index. Moreover, a further series of nested mixed ANOVA was conducted on weed density, rice yield, and harvest index, excluding the control, by considering the following factors: cover crop, termination nested in the cover crop, zone nested in termination nested in cover crop, year as a random factor and the interaction between year and the cover crop. Because the interaction was often significant, the analysis was performed separately per year. Mean separation was performed using Tukey post-hoc test, and differences between treatments were considered significant at $\mathrm{P} \leq 0.05$. The homogeneity of variances was tested using the Levene's test, and whenever the assumptions were violated, the data were subjected to square root transformation before analysis. The statistical analyses were conducted by using the Software IBM SPSS statistics, version 26 .

\section{Results}

\section{Cover crop biomass before termination}

At Rovasenda, the mixed ANOVA showed a significant interaction between cover crop biomass and year. In 2017, no differences were found in biomass of different cover crops, with values that were slightly above $1 \mathrm{t} \mathrm{ha}^{-1}$ dry matter (Table 1). In 2018, the lowest biomass values were recorded for hairy vetch $\left(0.7 \mathrm{t} \mathrm{ha}^{-1}\right.$ dry matter), while higher values (above $5 \mathrm{t} \mathrm{ha}^{-1}$ dry matter) were recorded for Italian ryegrass and the mix.

At Livorno Ferraris, the ANOVA showed no significant effects of the cover crops and the year on the cover crop biomass (Table 1). The recorded biomass values ranged between about $2 \mathrm{tha}^{-1}$ dry matter for hairy vetch and values slightly above $4 \mathrm{tha}^{-1}$ dry matter for Italian ryegrass and mix in 2018.

\section{Weed density, weed cover, and neighbour effect index}

\section{Rovasenda}

The analysis carried out on the assessment of weeds performed before cover crop termination highlighted a significant effect of the cover crop factor (including the control) on weed density, while the effect of the year was not significant (Table 2S). The significant effect of the cover crop factor was due to the significantly higher weed density values recorded in the control, with more than 30 plants $\mathrm{m}^{-2}$ in both years, compared to the different cover crops (Table 2). On the other hand, non-significant different weed densities between cover crops were found even though the weed density values ranged between about 5 and 19 plants $\mathrm{m}^{-2}$ (Table 2).

The ANOVA carried out to assess the effect of the cover crop (including the control) on weed density in June and July always highlighted a significantly higher weed density in the control. In June 2017, the weed density of the control showed similar values to that of the Italian ryegrass, while in 2018 , the control displayed similar values to that of the hairy vetch (Table 2; Table 2S).

The analysis carried out to assess the effect of the cover crops (excluding the control), the termination technique, and the zone on weed density showed a significant effect of the interaction between cover crops and year in June and July and of the termination technique and the the zone only in July (Table 3S).

Table 1. Aboveground plant biomass ( $\mathrm{t} \mathrm{ha} \mathrm{a}^{-1}$ dry matter \pm standard error) of the cover crop species at Rovasenda and Livorno Ferraris in 2017 and 2018.

\begin{tabular}{|c|c|c|}
\hline Cover crop & $\begin{array}{c}\text { Rovasenda } \\
\text { Cover crop biomass ( } \mathrm{t} \mathrm{ha}^{-1} \text { dry matter) }\end{array}$ & $\begin{array}{c}\text { Livorno Ferraris } \\
\text { Cover crop biomass ( } \text { ha }^{-1} \text { dry matter) }\end{array}$ \\
\hline & & \\
\hline Italian ryegrass & $1.2 \pm 0.2^{\mathrm{a}}$ & $2.7 \pm 0.4^{\mathrm{a}}$ \\
\hline Hairy vetch & $1.0 \pm 0.4^{\mathrm{a}}$ & $2.0 \pm 0.3^{\mathrm{a}}$ \\
\hline \multirow[t]{2}{*}{ Mix } & $0.8 \pm 0.1^{\mathrm{a}}$ & $3.6 \pm 0.6^{\mathrm{a}}$ \\
\hline & & \\
\hline Italian ryegrass & $5.6 \pm 0.2^{\mathrm{a}}$ & $4.3 \pm 0.3^{\mathrm{a}}$ \\
\hline Hairy vetch & $0.7 \pm 0.1^{b}$ & $1.9 \pm 0.4^{b}$ \\
\hline Mix & $5.2 \pm 0.2^{\mathrm{a}}$ & $4.2 \pm 0.3^{\mathrm{a}}$ \\
\hline
\end{tabular}

$\mathrm{a}, \mathrm{b}$ The same letters represent non-significant differences between cover crop values within the same site and year according to the Tukey test $(\mathrm{P} \leq 0.05)$. 
In June, weed density was different between cover crops only in 2018, in which the highest values were recorded in hairy vetch field with more than 160 plants $\mathrm{m}^{-2}$. In the assessment of June 2017, weed density recorded values higher than 100 plants $\mathrm{m}^{-2}$ for all the cover crops with a high presence of weedy rice (Oryza sati$v a \mathrm{~L}$.), especially in hairy vetch and in the mix fields (Figure 2A). The effect of the termination technique was only observed in mix 2017 and Italian ryegrass in 2018 with higher weedy density recorded for the shredded portion of the field, while for all the other cover crops, the effect of the different termination techniques on weeds was not evident (Table 3).

For the assessment on weeds carried out in June each year, the weed composition of the infestation and the calculation of the RNE were also shown (Figures 2 and 3). For example, in June 2018, weed density was composed in general by a low proportion of weedy rice and $H$. reniformis, while a high infestation of Lindernia dubia (L.) Pennell and Persicaria maculosa Gray, especially in hairy vetch and mix, were observed (Figure 2B).

The calculation on the RNE in 2017 and 2018 appeared dissimilar probably because the study was carried out in different fields having a different initial seed bank (Figure 3). In particular, in 2017, grass monocot species constituted mainly by weedy rice were suppressed by Italian ryegrass and only moderately by crimped mix. The other monocots, mainly represented by $H$. reniformis, were suppressed by all the tested cover crops, while the presence of dicotyledonous species was promoted when cover crops were present as no dicots were found in the control (Figure 3 ). In 2018, a general weed suppression ability of all the cover crops and termination techniques was found compared to the con-

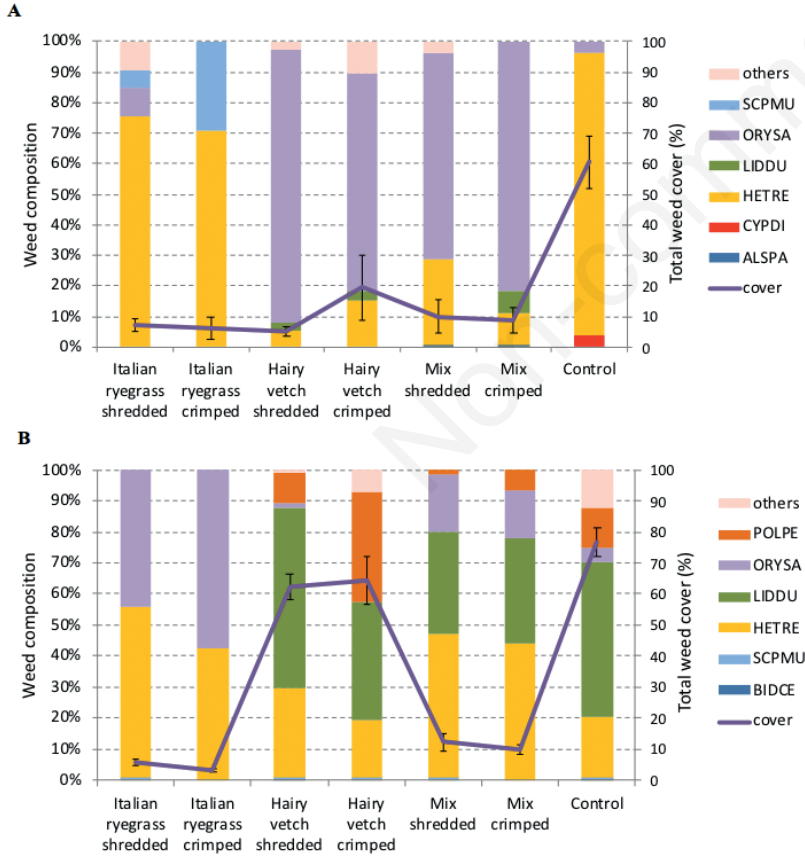

Figure 2. Weed species composition as a percentage of the total weed density at Rovasenda for the assessments conducted in June 2017 (A) and 2018 (B). SCPMU, Schoenoplectiella mucronate; ORYSA, Oryza sativa; LIDDU, Lindernia dubia; HETRE, Heteranthera reniformis; CYPDI, Cyperus difformis; ALSPA, Alisma plantago-aquatica, POLPE, Persicaria maculosa; BIDCE, Bidens cernua (EPPO codes). The purple line represents weed cover over the soil surface. trol, especially in the case of Italian ryegrass. On the other hand, the hairy vetch, particularly in the case of shredding, displayed a low suppressive ability, especially on the other monocots (mainly H. reniformis and Schoenoplectiella mucronata (L.) J. Jung \& H.K. Choi, with RNE=0.24) and on dicots (mainly L. dubia, with $\mathrm{RNE}=0.50)$.

\section{Livorno Ferraris}

The assessment on weeds carried out before termination in the cover crop fields, and in the control one, showed a significant interaction between cover crop and year (Table 2; Table 2S). This difference was due to the lower weed density recorded in the Italian ryegrass plot in 2018 , which counted only about 16 plants $\mathrm{m}^{-2}$ compared to more than 100 plants $\mathrm{m}^{-2}$ recorded in the other plots (Table 2). The assessment of June and July 2017 and June 2018 showed higher weed density in the control compared to the cover crops, while in July 2018, no differences between the plots were found (Table 2). It should be noted that weed infestation recorded in the control fields in June and July for both years showed a high presence of $H$. reniformis plants, which could not be counted in July as they formed a dense cover over the soil surface.

In the analysis in which the control was excluded, the cover crop plots showed similar values of weed density in the assessment carried out in June (Table 3; Table 3S). The most abundant species at the second assessment performed in June 2017 was Cyperus difformis L., which represented about $80 \%$ of the total number of species in the Italian ryegrass terminated with shredding and was also highly present in the field with the mix. On the other hand, Alopecurus geniculatus L. was dominant in the hairy vetch field, particularly in the shredded portion (Figure 4A).

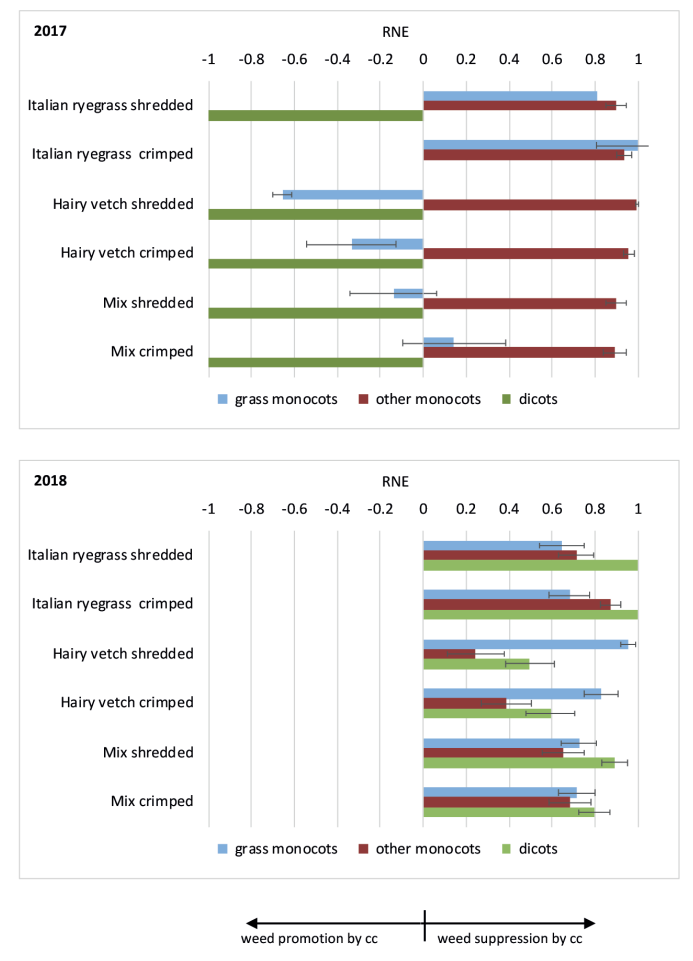

Figure 3. Relative neighbour effect (RNE) of the cover-crop at Rovasenda for the assessment carried out in June 2017 and 2018 for the three weed groups (grass monocots, other monocots, and dicots). Bars represent the standard error of the mean. cc, cover crops. 
Table 2. Effect of the cover crop and the control on weed density (plants $\mathbf{m}^{-2} \pm$ standard error) in the different fields at Rovasenda and Livorno Ferraris in 2017 and 2018. The weed density in July excluded the density of $\boldsymbol{H}$. reniformis.

\begin{tabular}{|c|c|c|c|c|c|c|}
\hline & $\begin{array}{l}\text { Before termination } \\
\text { Weed density } \\
\text { (plants } \mathrm{m}^{-2} \text { ) }\end{array}$ & $\begin{array}{l}\text { Rovasenda } \\
\text { June } \\
\text { Weed density } \\
\text { (plants } \mathrm{m}^{-2} \text { ) }\end{array}$ & $\begin{array}{l}\text { July } \\
\text { Weed density } \\
\text { (plants m-2) }\end{array}$ & $\begin{array}{l}\text { Before termination } \\
\text { Weed density } \\
\text { (plants } \mathrm{m}^{-2} \text { ) }\end{array}$ & $\begin{array}{l}\text { Livorno Ferraris } \\
\text { June } \\
\text { Weed density } \\
\text { (plants } \mathrm{m}^{-2} \text { ) }\end{array}$ & $\begin{array}{c}\text { July } \\
\text { Weed density } \\
\text { (plants } \mathrm{m}^{-2} \text { ) }\end{array}$ \\
\hline \multicolumn{7}{|c|}{2017} \\
\hline Italian ryegrass & $6.7 \pm 2.0^{\mathrm{b}}$ & $106.7 \pm 38.5^{\mathrm{a}}$ & $71.1 \pm 16.1^{\mathrm{b}}$ & $52.0 \pm 14.0^{\mathrm{a}}$ & $45.3 \pm 20.3^{\mathrm{b}}$ & $348.4 \pm 66.4^{\mathrm{a}}$ \\
\hline Hairy vetch & $16.0 \pm 2.8^{b}$ & $152.0 \pm 20.3^{b}$ & $73.8 \pm 18.4^{b}$ & $56.0 \pm 9.3^{\mathrm{a}}$ & $156.4 \pm 53.2^{\mathrm{b}}$ & $91.5 \pm 13.4^{b}$ \\
\hline Mix & $5.3 \pm 2.6^{\mathrm{b}}$ & $204.4 \pm 63.5^{b}$ & $89.8 \pm 21.7^{\mathrm{b}}$ & $18.7 \pm 5.4^{b}$ & $311.1 \pm 49.5^{b}$ & $487.1 \pm 78.2^{\mathrm{a}}$ \\
\hline Control & $44.4 \pm 10.5^{\mathrm{a}}$ & $935.1 \pm 152.9^{\mathrm{a}}$ & $394.7 \pm 59.0^{\mathrm{a}}$ & $65.1 \pm 4.8^{\mathrm{a}}$ & $1767.1 \pm 166.1^{\mathrm{a}}$ & $78.2 \pm 34.1^{\mathrm{b}}$ \\
\hline \multicolumn{7}{|c|}{2018} \\
\hline Italian ryegrass & $8.3 \pm 2.4^{b}$ & $20.4 \pm 2.1^{b}$ & $30.8 \pm 6.5^{b}$ & $16.0 \pm 7.0^{\mathrm{a}}$ & $130.7 \pm 37.1^{\mathrm{b}}$ & $124.9 \pm 26.0^{\mathrm{a}}$ \\
\hline Hairy vetch & $18.7 \pm 7.6^{\mathrm{b}}$ & $163.2 \pm 21.8^{\mathrm{a}}$ & $205.0 \pm 30.8^{\mathrm{a}}$ & $109.3 \pm 45.1^{\mathrm{a}}$ & $84.9 \pm 24.0^{\mathrm{b}}$ & $60.3 \pm 8.3^{\mathrm{a}}$ \\
\hline Mix & $7.6 \pm 2.6^{b}$ & $43.2 \pm 4.5^{b}$ & $53.9 \pm 6.8^{b}$ & $106.2 \pm 55.7^{\mathrm{a}}$ & $111.9 \pm 30.1^{\mathrm{b}}$ & $96.7 \pm 20.2^{\mathrm{a}}$ \\
\hline Control & $31.7 \pm 2.1^{\mathrm{a}}$ & $167.0 \pm 17.4^{\mathrm{a}}$ & $148.6 \pm 41.0^{a}$ & $133.2 \pm 15.8^{a}$ & $304.7 \pm 21.9^{a}$ & $121.2 \pm 46.6^{a}$ \\
\hline
\end{tabular}

a,bThe same letters represent non-significant differences between cover crop and control values according to the Tukey test $(\mathrm{P} \leq 0.05)$.

Table 3. Effect of the cover crop (excluding the control field) and the termination technique on weed density (plants $\mathrm{m}^{-2} \pm s t a n d a r d$ error) in the different fields at Rovasenda and Livorno Ferraris in 2017 and 2018. The weed density in July excluded the density of $H$. reniformis. Comparisons were made among cover crops (weed density cover) within the same site, assessment time, and year and between termination techniques (weed density termination) within each cover crop for the same site, assessment time, and year.

\begin{tabular}{|c|c|c|c|c|c|}
\hline Cover crop & Termination & $\begin{array}{c}\text { June } \\
\text { Weed density cover crop } \\
\text { (plants } \mathrm{m}^{-2} \text { ) }\end{array}$ & $\begin{array}{l}\text { Assessment } \\
\text { July } \\
\text { Weed density termination } \\
\text { (plants } \mathrm{m}^{-2} \text { ) }\end{array}$ & $\begin{array}{l}\text { time } \\
\text { Weed density cover crop } \\
\quad \text { (plants } \mathrm{m}^{-2} \text { ) }\end{array}$ & $\begin{array}{l}\text { Weed density termination } \\
\text { (plants } \mathrm{m}^{-2} \text { ) }\end{array}$ \\
\hline \multicolumn{6}{|c|}{ Rovasenda } \\
\hline \multicolumn{6}{|c|}{2017} \\
\hline Italian ryegrass & $\begin{array}{l}\text { Shredded } \\
\text { Crimped }\end{array}$ & $106.7 \pm 38.5^{\mathrm{a}}$ & $\begin{array}{l}152.9 \pm 65.6^{\mathrm{a}} \\
60.4 \pm 38.4^{\mathrm{a}}\end{array}$ & $71.1 \pm 16.1^{\mathrm{a}}$ & $\begin{array}{l}71.1 \pm 22.0^{\mathrm{a}} \\
71.1 \pm 24.9^{\mathrm{a}}\end{array}$ \\
\hline Hairy vetch & $\begin{array}{l}\text { Shredded } \\
\text { Crimped }\end{array}$ & $152.0 \pm 20.3^{\mathrm{a}}$ & $\begin{array}{c}131.55 \pm 19.0^{a} \\
172.4 \pm 61.8^{\mathrm{a}}\end{array}$ & $73.8 \pm 18.4^{\mathrm{a}}$ & $\begin{array}{l}85.5 \pm 19.4^{\mathrm{a}} \\
64.0 \pm 32.2^{\mathrm{a}}\end{array}$ \\
\hline Mix & $\begin{array}{l}\text { Shredded } \\
\text { Crimped }\end{array}$ & $204.4 \pm 63.5^{\mathrm{a}}$ & $\begin{array}{c}236.4 \pm 114.4^{\mathrm{a}} \\
172.4 \pm 61.8^{\mathrm{b}}\end{array}$ & $89.8 \pm 21.7^{\mathrm{a}}$ & $\begin{array}{l}142.2 \pm 34.7^{\mathrm{a}} \\
37.3 \pm 10.3^{\mathrm{b}}\end{array}$ \\
\hline \multicolumn{6}{|c|}{2018} \\
\hline Italian ryegrass & $\begin{array}{l}\text { Shredded } \\
\text { Crimped }\end{array}$ & $20.4 \pm 2.1^{b}$ & $\begin{array}{l}26.2 \pm 2.7^{\mathrm{a}} \\
14.6 \pm 1.6^{\mathrm{b}}\end{array}$ & $30.8 \pm 6.5^{b}$ & $\begin{array}{l}41.3 \pm 7.8^{\mathrm{a}} \\
20.3 \pm 9.4^{\mathrm{a}}\end{array}$ \\
\hline Hairy vetch & $\begin{array}{l}\text { Shredded } \\
\text { Crimped }\end{array}$ & $163.2 \pm 21.8^{a}$ & $\begin{array}{l}153.6 \pm 26.2^{\mathrm{a}} \\
172.9 \pm 36.2^{\mathrm{a}}\end{array}$ & $205.0 \pm 30.8^{a}$ & $\begin{array}{l}239.1 \pm 45.7^{\mathrm{a}} \\
171.0 \pm 40.4^{\mathrm{a}}\end{array}$ \\
\hline Mix & $\begin{array}{l}\text { Shredded } \\
\text { Crimped }\end{array}$ & $43.2 \pm 4.5^{b}$ & $\begin{array}{l}38.9 \pm 5.0^{\mathrm{a}} \\
47.4 \pm 7.5^{\mathrm{a}}\end{array}$ & $53.9 \pm 6.8^{b}$ & $\begin{array}{c}61.2 \pm 12.9^{\mathrm{a}} \\
46.7 \pm 4.5^{\mathrm{a}}\end{array}$ \\
\hline \multicolumn{6}{|c|}{$\begin{array}{l}\text { Livorno Ferraris } \\
\qquad 2017\end{array}$} \\
\hline Italian ryegrass & $\begin{array}{l}\text { Shredded } \\
\text { Crimped }\end{array}$ & $45.3 \pm 20.3^{\mathrm{a}}$ & $\begin{array}{l}32.0 \pm 26.5^{\mathrm{a}} \\
58.7 \pm 31.8^{\mathrm{a}}\end{array}$ & $348.4 \pm 66.4^{\mathrm{a}}$ & $\begin{array}{c}218.7 \pm 45.2^{\mathrm{b}} \\
478.2 \pm 111.7^{\mathrm{a}}\end{array}$ \\
\hline Hairy vetch & $\begin{array}{l}\text { Shredded } \\
\text { Crimped }\end{array}$ & $156.4 \pm 53.2^{\mathrm{a}}$ & $\begin{array}{c}85.3 \pm 33.1^{\mathrm{a}} \\
227.5 \pm 98.3^{\mathrm{a}}\end{array}$ & $91.5 \pm 13.4^{b}$ & $\begin{array}{l}87.1 \pm 15.6^{\mathrm{a}} \\
96.0 \pm 22.8^{\mathrm{a}}\end{array}$ \\
\hline Mix & $\begin{array}{l}\text { Shredded } \\
\text { Crimped }\end{array}$ & $311.1 \pm 49.5^{\mathrm{a}}$ & $\begin{array}{l}492.4 \pm 282.0^{\mathrm{a}} \\
129.8 \pm 85.0^{\mathrm{a}}\end{array}$ & $487.1 \pm 78.2^{\mathrm{a}}$ & $\begin{array}{l}627.5 \pm 133.4^{\mathrm{a}} \\
346.7 \pm 57.2^{\mathrm{a}}\end{array}$ \\
\hline \multicolumn{6}{|c|}{2018} \\
\hline Italian ryegrass & $\begin{array}{l}\text { Shredded } \\
\text { Crimped }\end{array}$ & $130.7 \pm 37.1^{\mathrm{a}}$ & $\begin{array}{l}37.3 \pm 14.8^{\mathrm{b}} \\
224.0 \pm 58.9^{\mathrm{a}}\end{array}$ & $124.9 \pm 26.0^{\mathrm{a}}$ & $\begin{array}{c}98.1 \pm 18.4^{\mathrm{a}} \\
151.7 \pm 48.5^{\mathrm{a}}\end{array}$ \\
\hline Hairy vetch & $\begin{array}{l}\text { Shredded } \\
\text { Crimped }\end{array}$ & $84.9 \pm 24.0^{\mathrm{a}}$ & $\begin{array}{l}83.6 \pm 39.7^{\mathrm{a}} \\
86.2 \pm 29.7^{\mathrm{a}}\end{array}$ & $60.3 \pm 8.3^{a}$ & $\begin{array}{l}63.9 \pm 11.4^{\mathrm{a}} \\
56.7 \pm 12.8^{\mathrm{a}}\end{array}$ \\
\hline Mix & $\begin{array}{l}\text { Shredded } \\
\text { Crimped }\end{array}$ & $111.9 \pm 30.1^{\mathrm{a}}$ & $\begin{array}{l}107.3 \pm 43.0^{\mathrm{a}} \\
116.5 \pm 44.6^{\mathrm{a}}\end{array}$ & $96.7 \pm 20.2^{\mathrm{a}}$ & $\begin{array}{l}99.8 \pm 20.7^{\mathrm{a}} \\
93.6 \pm 36.2^{\mathrm{a}}\end{array}$ \\
\hline
\end{tabular}

$a, b T h e$ same letters represent non-significant differences between values according to the Tukey test $(\mathrm{P} \leq 0.05)$. 
Weed species composition in June 2018 was mainly constituted by $H$. reniformis, which was highly represented in all fields, especially in crimped hairy vetch, while $A$. geniculatus was less observed than the preceding year (Figure 4B).

Weed soil cover over the soil surface exceeded $55 \%$ in the control fields in both years, while in the fields hosting the cover crops, it ranged between less than 10\% (2017) up to almost 50\% (2018 hairy vetch), probably because the weeds were still small (Figure $4 \mathrm{~A}$ and $\mathrm{B})$.

In the assessment of June, the weed suppression effect of the cover crops compared to the control was also calculated through the RNE index, and a different trend of this index was observed in the two years (Figure 5). In 2017, all the cover crops and termination techniques were able to suppress weeds better than the control, especially in the case of dicots. In 2018 however, the dicots, mainly constituted by Ammania coccinea Rottb. and Ranunculus sceleratus L., were instead promoted by all the cover crops as they were absent in the control field. On the other hand, higher suppression was exerted against monocots, in particular on grasses (weedy rice and Echinochloa crus-galli (L.) P. Beauv.), with higher suppression displayed by Italian ryegrass (Figure 5).

At the final assessment (July), the effect of the termination technique, and the interaction between year and cover crops (excluding the control), resulted significant in weed density (Table 3; Table 3S). In July 2017, hairy vetch showed the lowest weed density, about 91 plants $\mathrm{m}^{-2}$, while Italian ryegrass and the mix showed significantly higher infestation, exceeding 300 plants $\mathrm{m}^{-2}$. These differences between cover crops were not found in 2018, in which even though the infestation of hairy vetch showed lower
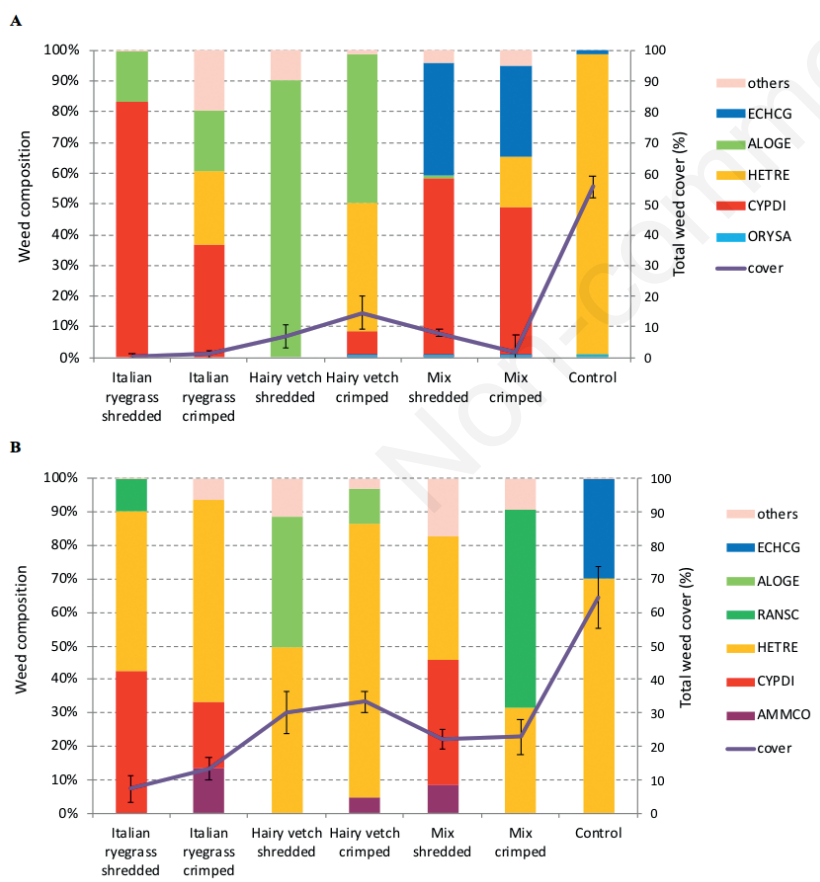

\footnotetext{
Figure 4. Weed species composition as a percentage of the total weed density at Livorno Ferraris for the assessments conducted in June 2017 (A) and 2018 (B). ECHCG, Echinochloa crus-galli; ALOGE, Alopecurus geniculatus; HETRE, Heteranthera reniformis; CYPDI, Cyperus difformis; ORYSA, Oryza sativa; RANSC, Ranunculus sceleratus; AMMCO, Ammania coccinea (EPPO codes). The purple line represents weed cover over the soil surface.
}

values than the other cover crops, this was not statistically different. The effect of the termination technique was only evident for Italian ryegrass in 2017 , in which crimping the cover crop caused a doubling of the weed density compared to the shredded part of the field (Table 3).

\section{Rice yield}

\section{Rovasenda}

Rice yield recorded in the control field showed significantly lower values than that recorded in the cover crops in both years (Table 4; Table 4S). The harvest index in 2017 showed higher values in the hairy vetch and lower in the control, while in 2018, the mix recorded higher values and the control the lowest (Table 4). The ANOVA on rice yield, excluding the control, highlighted a significant effect of the termination, the year, and the interaction between cover crop and year (Table 5S). The analysis separated per year showed similar yield values in 2017, both between cover crops and termination techniques, with values of about $3 \mathrm{tha}^{-1}$ (Table 5). In 2018, rice yield recorded higher values than 2017 , with hairy vetch showing the lowest yield (about $4 \mathrm{t} \mathrm{ha}^{-1}$ ), and Italian ryegrass and mix the highest values (about $5 \mathrm{t} \mathrm{ha}^{-1}$ ). The termination technique adopted on cover crops influenced rice yield only for mix in 2018, in which shredding the cover crop resulted in higher rice yield $\left(6 \mathrm{t} \mathrm{ha}^{-1}\right)$ than crimping (about $\left.4 \mathrm{t} \mathrm{ha}^{-1}\right)$ (Table 5).

The ANOVA analysis, excluding the control, on harvest index showed a significant effect of cover crop, termination technique, and the interaction between year and cover crop (Table 5S). The harvest index only showed differences between cover crops in

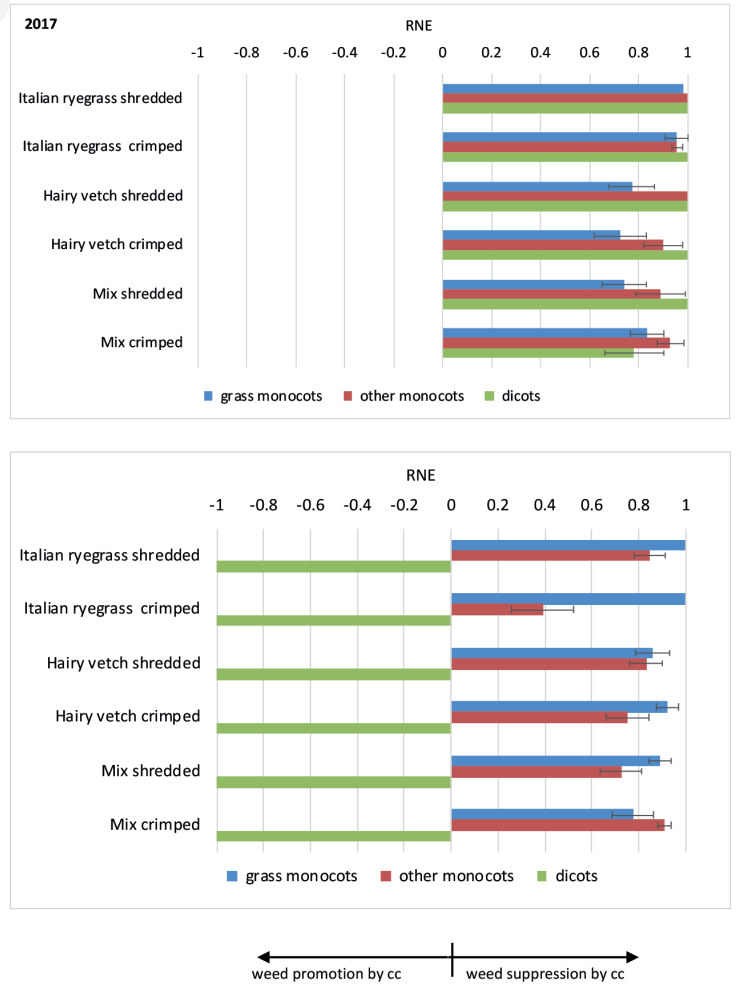

Figure 5. Relative neighbour effect (RNE) of the cover-crop at Livorno Ferraris for the assessment carried out in June 2017 and 2018 for the three weed groups (grass monocots, other monocots, and dicots). Bars represent the standard error of the mean. cc, cover crops. 
2017 in which hairy vetch displayed significantly lower values (0.5) than the other cover crops. The termination technique affected the harvest index only in Italian ryegrass in 2017 and the mix in 2018; in both cases, the highest values were recorded for shredding (Table 4).

\section{Livorno Ferraris}

Rice yield was affected by cover crops and year when the control was included in the analysis; separating the analysis between years, in 2017, the control and the hairy vetch showed the highest

Table 4. Effect of the cover crop and the control on rice yield ( $\mathrm{tha}^{-1} \pm$ standard error) and harvest index ( \pm standard error) in the different fields at Rovasenda and Livorno Ferraris in 2017 and 2018.

\begin{tabular}{|c|c|c|c|c|}
\hline & \multicolumn{2}{|c|}{ Rovasenda } & \multicolumn{2}{|c|}{ Livorno Ferraris } \\
\hline \multicolumn{5}{|c|}{2017} \\
\hline Italian ryegrass & $3.6 \pm 0.3^{\mathrm{a}}$ & $0.6 \pm 0.0^{\mathrm{ab}}$ & $2.2 \pm 0.3^{\mathrm{ab}}$ & $0.3 \pm 0.0^{\mathrm{a}}$ \\
\hline Hairy vetch & $3.2 \pm 0.2^{\mathrm{a}}$ & $0.5 \pm 0.0^{b}$ & $3.4 \pm 0.2^{\mathrm{a}}$ & $0.2 \pm 0.0^{\mathrm{a}}$ \\
\hline Mix & $3.6 \pm 0.3^{\mathrm{a}}$ & $0.6 \pm 0.0^{\mathrm{a}}$ & $1.2 \pm 0.2^{b}$ & $0.2 \pm 0.0^{\mathrm{a}}$ \\
\hline Control & $1.6 \pm 0.1^{b}$ & $0.4 \pm 0.0^{c}$ & $3.1 \pm 0.5^{\mathrm{a}}$ & $0.2 \pm 0.0^{\mathrm{a}}$ \\
\hline \multicolumn{5}{|c|}{2018} \\
\hline Italian ryegrass & $5.3 \pm 0.2^{\mathrm{a}}$ & $0.3 \pm 0.0^{\mathrm{ab}}$ & $4.5 \pm 0.3^{\mathrm{ab}}$ & $0.4 \pm 0.0^{\mathrm{a}}$ \\
\hline Hairy vetch & $4.3 \pm 0.2^{\mathrm{a}}$ & $0.3 \pm 0.0^{\mathrm{ab}}$ & $4.7 \pm 0.4^{\mathrm{a}}$ & $0.3 \pm 0.0^{\mathrm{a}}$ \\
\hline Mix & $5.2 \pm 0.4^{\mathrm{a}}$ & $0.4 \pm 0.0^{\mathrm{a}}$ & $5.2 \pm 0.2^{\mathrm{a}}$ & $0.3 \pm 0.0^{\mathrm{a}}$ \\
\hline Control & $2.6 \pm 0.3^{b}$ & $0.3 \pm 0.0^{b}$ & $3.0 \pm 0.4^{b}$ & $0.3 \pm 0.0^{\mathrm{a}}$ \\
\hline
\end{tabular}

a-cThe same letters represent non-significant differences between cover crop and control values according to the Tukey test $(\mathrm{P} \leq 0.05)$.

Table 5. Effect of the cover crop (excluding the control field) and the termination technique on rice yield ( $\left.t \mathrm{ha}^{-1} \pm s t a n d a r d ~ e r r o r\right)$ and harvest index ( \pm standard error) in the different fields at Rovasenda and Livorno Ferraris in 2017 and 2018. Comparisons were made among cover crops (rice yield cover crop and harvest index cover crop) within the same site and year and between termination techniques (rice yield termination and harvest index termination) within each cover crop for the same site and year.

\begin{tabular}{|c|c|c|c|c|c|}
\hline Cover crop & Termination & $\begin{array}{l}\text { Rice yield } \\
\text { cover crop } \\
\left(\mathrm{t} \mathrm{ha}^{-1}\right)\end{array}$ & $\begin{array}{c}\text { Rice yield } \\
\text { termination } \\
\left(\mathrm{t} \mathrm{ha} \mathrm{h}^{-1}\right) \\
\text { Rovasenda }\end{array}$ & $\begin{array}{c}\text { Harvest index } \\
\text { cover crop }\end{array}$ & $\begin{array}{c}\text { Harvest index } \\
\text { termination }\end{array}$ \\
\hline \multicolumn{6}{|c|}{2017} \\
\hline Italian ryegrass & $\begin{array}{l}\text { Shredded } \\
\text { Crimped }\end{array}$ & $3.6 \pm 0.3^{\mathrm{a}}$ & $\begin{array}{l}3.5 \pm 0.3^{\mathrm{a}} \\
3.7 \pm 0.6^{\mathrm{a}}\end{array}$ & $0.6 \pm 0.0^{\mathrm{a}}$ & $\begin{array}{l}0.6 \pm 0.0^{\mathrm{a}} \\
0.5 \pm 0.0^{\mathrm{b}}\end{array}$ \\
\hline Hairy vetch & $\begin{array}{l}\text { Shredded } \\
\text { Crimped }\end{array}$ & $3.2 \pm 0.2^{\mathrm{a}}$ & $\begin{array}{l}2.9 \pm 0.2^{\mathrm{a}} \\
3.5 \pm 0.2^{\mathrm{a}}\end{array}$ & $0.5 \pm 0.0^{b}$ & $\begin{array}{l}0.5 \pm 0.0^{\mathrm{a}} \\
0.5 \pm 0.0^{\mathrm{a}}\end{array}$ \\
\hline Mix & $\begin{array}{l}\text { Shredded } \\
\text { Crimped }\end{array}$ & $3.6 \pm 0.3^{\mathrm{a}}$ & $\begin{array}{l}3.6 \pm 0.2^{\mathrm{a}} \\
3.5 \pm 0.2^{\mathrm{a}}\end{array}$ & $0.6 \pm 0.0^{\mathrm{a}}$ & $\begin{array}{l}0.6 \pm 0.0^{\mathrm{a}} \\
0.6 \pm 0.0^{\mathrm{a}}\end{array}$ \\
\hline \multicolumn{6}{|c|}{2018} \\
\hline Italian ryegrass & $\begin{array}{l}\text { Shredded } \\
\text { Crimped }\end{array}$ & $5.3 \pm 0.2^{\mathrm{a}}$ & $\begin{array}{l}5.3 \pm 0.5^{\mathrm{a}} \\
5.3 \pm 0.0^{\mathrm{a}}\end{array}$ & $0.3 \pm 0.0^{\mathrm{a}}$ & $\begin{array}{l}0.4 \pm 0.0^{\mathrm{a}} \\
0.3 \pm 0.0^{\mathrm{a}}\end{array}$ \\
\hline Hairy vetch & $\begin{array}{l}\text { Shredded } \\
\text { Crimped }\end{array}$ & $4.3 \pm 0.2^{b}$ & $\begin{array}{l}4.0 \pm 0.3^{a} \\
4.7 \pm 0.2^{a}\end{array}$ & $0.3 \pm 0.0^{a}$ & $\begin{array}{l}0.3 \pm 0.0^{\mathrm{a}} \\
0.3 \pm 0.0^{\mathrm{a}}\end{array}$ \\
\hline Mix & $\begin{array}{l}\text { Shredded } \\
\text { Crimped }\end{array}$ & $5.2 \pm 0.4^{\mathrm{a}}$ & $\begin{array}{l}6.1 \pm 0.1^{\mathrm{a}} \\
4.3 \pm 0.4^{\mathrm{b}}\end{array}$ & $0.4 \pm 0.0^{\mathrm{a}}$ & $\begin{array}{l}0.4 \pm 0.0^{\mathrm{a}} \\
0.3 \pm 0.0^{\mathrm{b}}\end{array}$ \\
\hline \multicolumn{6}{|c|}{$\begin{array}{l}\text { Livorno Ferraris } \\
2017\end{array}$} \\
\hline Italian ryegrass & $\begin{array}{l}\text { Shredded } \\
\text { Crimped }\end{array}$ & $2.2 \pm 0.3^{b}$ & $\begin{array}{l}2.4 \pm 0.1^{\mathrm{a}} \\
2.0 \pm 0.7^{\mathrm{a}}\end{array}$ & $0.3 \pm 0.0^{\mathrm{a}}$ & $\begin{array}{l}0.3 \pm 0.0^{\mathrm{a}} \\
0.3 \pm 0.0^{\mathrm{a}}\end{array}$ \\
\hline Hairy vetch & $\begin{array}{l}\text { Shredded } \\
\text { Crimped }\end{array}$ & $3.4 \pm 0.2^{\mathrm{a}}$ & $\begin{array}{l}3.2 \pm 0.5^{\mathrm{a}} \\
3.5 \pm 0.2^{\mathrm{a}}\end{array}$ & $0.2 \pm 0.0^{b}$ & $\begin{array}{l}0.2 \pm 0.0^{\mathrm{a}} \\
0.2 \pm 0.0^{\mathrm{a}}\end{array}$ \\
\hline Mix & $\begin{array}{l}\text { Shredded } \\
\text { Crimped }\end{array}$ & $1.2 \pm 0.2^{b}$ & $\begin{array}{l}1.5 \pm 0.4^{\mathrm{a}} \\
1.0 \pm 0.2^{\mathrm{a}}\end{array}$ & $0.2 \pm 0.0^{\mathrm{a}}$ & $\begin{array}{l}0.3 \pm 0.0^{\mathrm{a}} \\
0.2 \pm 0.0^{\mathrm{a}}\end{array}$ \\
\hline \multicolumn{6}{|c|}{2018} \\
\hline Italian ryegrass & $\begin{array}{l}\text { Shredded } \\
\text { Crimped }\end{array}$ & $4.5 \pm 0.3^{\mathrm{a}}$ & $\begin{array}{l}5.1 \pm 0.3^{\mathrm{a}} \\
3.9 \pm 0.5^{\mathrm{a}}\end{array}$ & $0.4 \pm 0.0^{\mathrm{a}}$ & $\begin{array}{l}0.4 \pm 0.0^{\mathrm{a}} \\
0.3 \pm 0.0^{\mathrm{a}}\end{array}$ \\
\hline Hairy vetch & $\begin{array}{l}\text { Shredded } \\
\text { Crimped }\end{array}$ & $4.7 \pm 0.4^{\mathrm{a}}$ & $\begin{array}{l}5.5 \pm 0.1^{\mathrm{a}} \\
3.8 \pm 0.3^{\mathrm{b}}\end{array}$ & $0.3 \pm 0.0^{\mathrm{a}}$ & $\begin{array}{l}0.3 \pm 0.0^{\mathrm{a}} \\
0.3 \pm 0.0^{\mathrm{a}}\end{array}$ \\
\hline Mix & $\begin{array}{l}\text { Shredded } \\
\text { Crimped }\end{array}$ & $5.2 \pm 0.2^{\mathrm{a}}$ & $\begin{array}{l}5.5 \pm 0.1^{\mathrm{a}} \\
4.8 \pm 0.3^{\mathrm{a}}\end{array}$ & $0.3 \pm 0.0^{\mathrm{a}}$ & $\begin{array}{l}0.3 \pm 0.0^{\mathrm{a}} \\
0.3 \pm 0.0^{\mathrm{a}}\end{array}$ \\
\hline
\end{tabular}

a,bThe same letters represent non-significant differences between values according to the Tukey test $(\mathrm{P} \leq 0.05)$ 
values, while in 2018, the control displayed the lowest yield (Table 4S; Table 4). However, the harvest index of rice in the control field was similar to that of rice grown in cover crop fields in both years (Table 4S; Table 4).

In the analysis in which the control was excluded, the highest yield was recorded in hairy vetch in 2017, while in 2018, no differences between rice yields were found, but the average yield values almost reached $5 \mathrm{t} \mathrm{ha}^{-1}$ in all the fields (Table 5; Table 5S). The termination technique did not affect rice yield, except hairy vetch in 2018 in which shredding the cover crop permitted higher yields (Table 5). Harvest index was not affected by cover crop and termination technique, while differences were found in the two years of the study, with higher values in 2018 (Table 5S).

\section{Discussion}

The study highlighted that the cultivation of cover crops in winter could reduce weed pressure during the rice cropping season more than fallow (control fields), resulting in a consequent higher rice production in most cases. In fact, the fields cultivated with cover crops during the intercropping period, either terminated by shredding or by roller-crimping, often resulted in lower weed density compared to control (Table 2). Furthermore, the weed suppressive ability of cover crops was related to their development as at Rovasenda in 2017, the cover crop biomass was low due to poor emergence caused by sod-seeding, and the suppressive effect was limited as shown by RNE (Figure 3). On the contrary, in 2018 at Rovasenda and at Livorno Ferraris, where the cover crops showed a better soil cover as demonstrated by the higher biomass production, weeds were much more suppressed in general. A confirmation of this evidence comes from previous studies that highlighted the importance of a rapid cover crop emergence, high soil cover, and good biomass production for an effective weed limitation (Brust et al., 2014). Moreover, it has also been established that sowing cover crops in tilled soil resulted in a higher emergence due to a better seed hydration consequent to soil-seed contact, which is often hampered when many residues are present on the soil surface, as in the case of non-tilled fields (Gerhards and Schappert, 2020).

In this study, weed density was estimated both before and after cover crop termination to distinguish between the sole effect of living cover crop competition and the effect of green mulching, which can be considered a combined effect of mulching and phytotoxicity due to residue fermentation in the presence of water.

The assessment carried out before cover crop termination highlighted a lower weed density in the fields with cover crops compared to control at both sites in both years, and this difference was also maintained after termination. However, among the cover crops, hairy vetch fields at both sites recorded slightly higher weed density even though not always significantly different than that of the other cover crops due to poor cover crop establishment, as demonstrated by the lower biomass recorded before termination, especially at Rovasenda in 2018 as a consequence of repeated frost events.

The lower weed density during the cover crop cultivation can be attributed to competition for nutrients, water, space, and light due to the shading of the cover crops (Brust et al., 2014; MacLaren et al., 2019). Therefore, the use of living cover crops in the fallow period may help to reduce the number of weeds able to produce seeds and shading the seeds present in the soil surface disfavouring their germination; this would partly contribute to a less dense weed cover in spring (Hiltbrunner et al., 2007; Fogliatto et al., 2020a).
After cover crop termination and field flooding, it was possible to assess the effects of green mulching on weed development. Also, in this case, weed density and especially weed cover were reduced with green mulching compared to the absence of cover crops. In fact, weed density in the control at the beginning of June recorded more than 1700 plants $\mathrm{m}^{-2}$ at Livorno Ferraris and more than 900 plants $\mathrm{m}^{-2}$ at Rovasenda, a level of infestation able to cause a significant rice yield reduction. Nevertheless, weed infestation in the fields hosting the cover crops was also very high, especially in crimped hairy vetch plot at Rovasenda in 2018 and in the mix and Italian ryegrass at Livorno Ferraris in 2017. This high weed infestation is probably due to a lack of cover crop establishment caused by limited germination or biomass reduction due to cold winter temperature, and late spring frost at both sites (Figure 1). These results highlighted that cover crops used as green mulch can limit weed infestations. However, if this technique is used as the only weed management practice, it is not sufficient to limit weed development effectively. As shown, weed suppressive effects of green mulching obtained using cover crops may not last for all the growing season due to inadequate biomass production and fast residue decomposition (Osipitan et al., 2019).

Weed suppression ability is linked to the type of cover crop species as also demonstrated in this study, in which the different species showed a variable behaviour. Moreover, even within a cover crop species, a variable weed limiting ability was shown between sites and years probably because of the different environmental conditions that the species experienced, which affected their development. Hairy vetch, for example, favoured weed growth at Rovasenda in 2018 as its establishment was scarce due to the low germination in sod-seeding conditions and its cold sensitivity, which almost determined a total cover crop failure. However, at Livorno Ferraris, even though the temperatures were lower than those recorded at Rovasenda, the cover crops were sown in tilled fields, weed density in the vetch fields was moderate, resulting in a high rice yield in both years. Previous studies also showed a cold sensitivity of hairy vetch and low emergence in case of no-tillage; the combination of these factors at Rovasenda caused a reduced weed suppression, recording weed density similar to fallow (Hayden et al., 2015; Renzi et al., 2017; AlonsoAyuso et al., 2018). Thus, the use of hairy vetch as a cover crop could be a good option in warmer areas and when the soil is tilled before seeding to guarantee a good crop establishment (Hayden et al., 2015; Renzi et al., 2017; Osipitan et al., 2019). High emergence in different soil conditions, cold tolerance, and fall competitiveness are traits that should be considered when choosing cover crop species as they are essential in determining the weed density in the spring (Brust et al., 2014).

In our study, Italian ryegrass showed better tolerance to cold temperatures and displayed a good emergence, even in non-tilled soil, in both years and sites; this resulted in a higher and more homogeneous soil cover in spring, which acted as a physical barrier towards weeds. Generally, the results obtained with Italian ryegrass were similar with both termination techniques except for Livorno Ferraris in 2017. Although, at this site, better weed control was obtained in the shredded Italian ryegrass portion as in the crimped one, some plants were not wholly terminated and able to stand again for sometimes during flooding; this might have reduced both the mulching and the fermentation effects. It has been observed that incomplete termination may reduce the yield of the main crop through competition and by reducing crop emergence due to limited soil warming in the spring (Cornelius and Bradley, 2017a). Previous studies confirmed the higher adaptability in various pedo-climatic conditions and a rapid biomass accumulation of 
Italian ryegrass compared to vetch and the consequent good suppression of weeds in the spring (Hodgdon et al., 2016; Cornelius and Bradley, 2017b).

The mixture of different cover crops showed a variable weed suppressive effect. The same happened in 2018 at Rovasenda, when the weed density was quite limited, and the rice yield was the highest (about $6 \mathrm{t} \mathrm{ha}^{-1}$ ), while at Livorno Ferraris, weed density was almost always very high with meager rice yield in 2017 . The mixture's better performance at Rovasenda might be due to the higher number of cover crop species present in the mixture that probably compensate for growth variations in time and space among species, even though this was not clearly tested in this experiment. Some previous studies highlighted a better weed control for mixture than single cover crops, even though results were often inconsistent between studies, as observed in our experiment (Alonso-Ayuso et al., 2018; MacLaren et al., 2019). Better performance of the mixture than hairy vetch at Rovasenda might also be due to the better emergence of Italian ryegrass in non-tilled soil and its faster growth in the fall that can have protected vetch from the cold (Hayden et al., 2015). Moreover, it has been observed that the higher grass cover crop suppression over weeds compared to broadleaf cover crops can also be attributed to a higher residue persistence after termination (Osipitan et al., 2019).

In this study, the effect of the different termination techniques of the cover crop on weeds and rice yield was almost not evident because it was not significant in the majority of the cases, or it was confounded with the effect of the cover crop. Only in few cases, the effect of the termination technique was significant, displaying a better performance with shredding than crimping. It has been hypothesized that as shredding cuts in small parts the vegetation, this may promote a faster degradation than crimping (RosarioLebron et al., 2019); moreover, this could have slightly promoted the fermentation in flooding conditions.

The most abundant weeds found in the experimental fields were weedy rice, E. crus-galli, C. difformis, and H. reniformis. Referring to the first three species, their vigour permitted them to emerge through the terminated cover crop, causing their spreading and favouring the infestation in rice. Heteranthera reniformis was the most observed weed in all fields but particularly in hairy vetch due to poor development of the species as many areas of bare soil were present. In these conditions, this species was able to germinate after flooding and, in some cases, to grow over the terminated cover crop, competing with rice and vanishing the cover crop effects.

The study did not aim to evaluate if the weed suppressive effect of cover crops was mainly due to physical growth limitation or to phytotoxic compounds developed during fermentation. However, it is possible to hypothesize that both phenomena contributed to weed suppression. The presence of mulching could have reduced weed seed germination as under the cover crop layer, the temperature variations are small and light penetration can be hampered, even though some studies reported higher weed germination and emergence due to higher moisture and nitrogen release from cover crop after termination (Bavougian et al., 2018; AlonsoAyuso et al., 2018). Weed emergence and growth, however, can be hindered by the physical interference of the cover crop layer (Brust et al., 2014).

The release of phytotoxic substances from cover crop residues and organic acid production, such as acetic acid, during fermentation in flooded conditions may have played a role in weed suppression. In addition, these substances can also affect rice germination, causing yield losses as rice germinates on the soil surface while the fermentation processes are active (Alonso-Ayuso et al., 2018).
However, contrasting results regarding promotion or inhibition of seed germination due to organic acid production can be found in the literature, but the presence of these molecules seems able to cause shoot and root reduction (Camargo et al., 2001).

\section{Conclusions}

The study highlighted that cover crop green mulching in rice could be a valuable technique to reduce weed pressure even though it has to be seen as a method that should be integrated with other chemical and non-chemical techniques applied in the cropping season.

In the fallow period, green mulching can substitute stubble tillage or the use of non-selective herbicides, reducing weed infestation while providing other positive effects.

Further studies will be needed to clarify the relative importance of the mulching effect and the release of phytotoxic substances during fermentation on weed suppression. Furthermore, the most suitable length of the flooding period after termination, able to maximize the limitation of weed development while not suppressing rice emergence, has still to be found. Moreover, the study highlighted a higher difference between cover crop species in terms of growth and competitive ability against weeds; thus further cover crop species should be tested with this technique. Finally, the termination technique seems to have a negligible effect on the success of green mulching; however, different techniques and timings of termination should be evaluated to confirm this result.

\section{References}

Ackroyd V, Flessner M, Mirsky S, Pittman K, Rubione C, Shergill L, VanGessel M, 2019. Considerations for terminating cover crops for weed management. Get Rid Of Weeds Through Integrated Weed Management, GROW Bulletin 02. Available from: www.growiwm.org

Alonso-Ayuso M, Gabriel JL, García-González I, Del Monte JP, Quemada M, 2018. Weed density and diversity in a long-term cover crop experiment background. Crop Prot. 112:103-11.

Andres A, Fogliatto S, Ferrero A, Vidotto F, 2014. Susceptibility to imazamox in Italian weedy rice populations and Clearfield $\AA$ rice varieties. Weed Res. 54:492-500.

Arpa Piemonte, 2021. Available from: https://www.arpa. piemonte.it/rischinaturali/tematismi/clima/confronti-storici/ temperatura/Media_climatologica. html?delta $=4$

Bavougian CM, Sarno E, Knezevic S, Shapiro CA, 2018. Cover crop species and termination method effects on organic maize and soybean. Biol. Agric. Hortic. 35:1-20.

Brust J, Claupein W, Gerhards R, 2014. Growth and weed suppression ability of common and new cover crops in Germany. Crop Prot. 63:1-8.

Camargo FA de O, Zonta E, Santos G de A, Rossiello ROP, 2001. Aspectos fisiológicos e caracterização da toxidez de ácidos orgânicos voláteis em plantas. Ciênc. Rural 31:523-9.

Chauhan BS, Singh VP, Kumar A, Johnson DE, 2011. Relations of rice seeding rates to crop and weed growth in aerobic rice. Field Crop Res 121:105-15.

Chauhan BS, 2012. Weed management indirect-seeded rice systems. IRRI International Rice Research Institute, Los Baños, Philippines. 
Cornelius CD, Bradley KW, 2017a. Herbicide programs for the termination of various cover crop species. Weed Technol. 31:514-22.

Cornelius CD, Bradley KW, 2017b. Influence of various cover crop species on winter and summer annual weed emergence in soybean. Weed Technol. 31:503-13.

Caporali F, Campiglia E, Mancinelli R, Paolini R, 2004. Maize performances as influenced by winter cover crop green manuring. Ital. J. Agron. 8:37-45.

Dass A, Shekhawat K, Choudhary AK, Sepat S, Rathore SS, Mahajan G, Chauhan BS, 2017. Weed management in rice using crop competition-a review. Crop Prot. 95:45-52.

Didon UME, Kolseth A-K, Widmark D, Persson P, 2014. Cover crop residues - effects on germination and early growth of annual weeds. Weed Sci. 62:294-302.

Dorn B, Stadler M, van der Heijden M, Streit B, 2013. Regulation of cover crops and weeds using a roll-chopper for herbicide reduction in no-tillage winter wheat. Soil Till. Res. 134:121-32.

Ente Nazionale Risi, 2021. Available from: https://www. enterisi.it/upload/enterisi/documentiallegati/Superficipergrupp i2020al31agosto-secondastima 13660 4683.pdf

Ferrero A, Fogliatto S, Barberi A, Vidotto F, 2020. Relationship between weedy rice (Oryza sativa) infestation level and agronomic practices in Italian rice farms. Weed Sci. 1-10.

Fogliatto S, De Palo F, Milan M, Patrucco L, Vidotto F, 2019. Weed control efficacy of cover crop as green mulching in rice cultivation. p 197 in G. Seddaiu, P. Benincasa (Eds.), Proceedings of XLVIII Conference of Italian Society for Agronomy, Perugia, Italy.

Fogliatto S, Ferrero A, Vidotto F, 2020a. Current and future scenarios of glyphosate use in Europe: Are there alternatives? In: DL Sparks (Ed.), Advances in agronomy, 163. Academic Press, Cambridge, USA, pp 219-78.

Fogliatto S, Ferrero A, Vidotto F, 2020b. How can weedy rice stand against abiotic stresses? A review. Agronomy 10:1284.

Gerhards R, Schappert A, 2020. Advancing cover cropping in temperate integrated weed management. Pest Manag. Sci. 76:42-6.

Hayden ZD, Ngouajio M, Brainard DC, 2015. Planting date and staggered seeding of rye-vetch mixtures: biomass, nitrogen, and legume winter survival. Agron. J. 107:33-40.

Hiltbrunner J, Liedgens M, Bloch L, Stamp P, Streit B, 2007. Legume cover crops as living mulches for winter wheat: Components of biomass and the control of weeds. Eur. J. Agron. 26:21-9.

Hodgdon EA, Warren ND, Smith RG, Sideman RG, 2016. In-season and carry-over effects of cover crops on productivity and weed suppression. Agron. J. 108:1624-35.

Kruidhof HM, van Dam NM, Ritz C, Lotz LAP, Kropff MJ, Bastiaans L, 2014. Mechanical wounding under field conditions: A potential tool to increase the allelopathic inhibitory effect of cover crops on weeds? Eur. J. Agron. 52:229-36.

Lamichhane JR, Dachbrodt-Saaydeh S, Kudsk P, Messéan A, 2016. Toward a reduced reliance on conventional pesticides in European agriculture. Plant Dis. 100:10-24.
Lounsbury NP, Weil RR, 2015. No-till seeded spinach after winterkilled cover crops in an organic production system. Renew. Agric. Food Syst. 30:473-85.

MacLaren C, Swanepoel P, Bennett J, Wright J, Dehnen-Schmutz $\mathrm{K}, 2019$. Cover crop biomass production is more important than diversity for weed suppression. Crop Sci. 59:733-48.

Orlando F, Alali S, Vaglia V, Pagliarino E, Bacenetti J, Bocchi S, 2020. Participatory approach for developing knowledge on organic rice farming: Management strategies and productive performance. Agr. Syst. 178:102739.

Osipitan OA, Dille JA, Assefa Y, Knezevic SZ, 2018. Cover crop for early season weed suppression in crops: systematic review and meta-analysis. Agron. J. 110:2211-21.

Osipitan OA, Dille JA, Assefa Y, Radicetti E, Ayeni A, Knezevic SZ, 2019. Impact of cover crop management on level of weed suppression: A meta-analysis. Crop Sci. 59:833-42.

Pardo G, Marí AI, Aibar J, Cirujeda A, 2021. Do crop rotations in rice reduce weed and Echinochloa spp. infestations? Recommendations for integrated weed control. Agronomy $11: 454$

Ranghetti L, Cardarelli E, Boschetti M, Busetto L, Fasola M, 2018. Assessment of water management changes in the Italian rice paddies from 2000 to 2016 using satellite data: a contribution to agro-ecological studies. Remote Sens. 10:416.

Renzi JP, Chantre GR, Cantamutto MA, 2017. Self-regeneration of hairy vetch (Vicia villosa Roth) as affected by seedling density and soil tillage method in a semi-arid agroecosystem. Grass Forage Sci. 72:524-33.

Rosario-Lebron A, Leslie AW, Yurchak VL, Chen G, Hooks CRR, 2019. Can winter cover crop termination practices impact weed suppression, soil moisture, and yield in no-till soybean [Glycine max (L.) Merr.]? Crop Prot. 116:132-41.

Serra F, Fogliatto S, Vidotto F, 2018. Effect of salinity on Echinochloa crus-galli germination as affected by herbicide resistance. Ital. J. Agron. 13:221-8.

Shekhawat K, Rathore SS, Chauhan BS, 2020. Weed management in dry direct-seeded rice: A review on challenges and opportunities for sustainable rice production. Agronomy 10:1264.

Smith R, Atwood LW, Pollnac FW, Warren N, 2015. Cover-crop species as distinct biotic filters in weed community assembly. Weed Sci. 63:282-95.

Stepanovic S, Datta A, Neilson B, Bruening C, Shapiro CA, Gogos G, Knezevic SZ, 2016. Effectiveness of flame weeding and cultivation for weed control in organic maize. Biol. Agric. Hortic. 32:47-62.

Vidotto F, Dalla Valle N, Fogliatto S, Milan M, De Palo F, Tabacchi M, Ferrero A, 2020. Rapid increase of herbicide resistance in Echinochloa spp. consequent to repeated applications of the same herbicides over time. Arch. Agron. Soil Sci. $1-13$.

Youngerman CZ, DiTommaso A, Curran WS, Mirsky SB, Ryan MR, 2018. Corn density effect on interseeded cover crops, weeds, and grain yield. Agron. J. 110:2478-87. 